\title{
AAV-mediated gene therapy for heart failure: enhancing contractility and calcium handling Fouad A. Zouein ${ }^{1,2}$ and George W. Booz ${ }^{1,2 *}$
}

Addresses: ${ }^{1}$ Department of Pharmacology and Toxicology, School of Medicine and The Jackson Center for Heart Research and ${ }^{2}$ The CardiovascularRenal Research Center, The University of Mississippi Medical Center, Jackson, Mississippi, USA

*Corresponding author: George W. Booz (gbooz@umc.edu)

Fl000Prime Reports 2013, 5:27 (doi:10.12703/P5-27)

This is an open-access article distributed under the terms of the Creative Commons Attribution-Non Commercial License (http://creativecommons.org/licenses/by-nc/3.0/legalcode), which permits unrestricted use, distribution, and reproduction in any medium, provided the original work is properly cited. You may not use this work for commercial purposes.

The electronic version of this article is the complete one and can be found at: http://fl 000.com/prime/reports/b/5/27

\begin{abstract}
Heart failure is a progressive, debilitating disease that is characterized by inadequate contractility of the heart. With an aging population, the incidence and economic burden of managing heart failure are anticipated to increase substantially. Drugs for heart failure only slow its progression and offer no cure. However, results of recent clinical trials using recombinant adeno-associated virus (AAV) gene delivery offer the promise, for the first time, that heart failure can be reversed. The strategy is to improve contractility of cardiac muscle cells by enhancing their ability to store calcium through increased expression of the sarco(endo)plasmic reticulum $\mathrm{Ca}^{2+}$-ATPase pump (SERCA2a). Preclinical trials have also identified other proteins involved in calcium cycling in cardiac muscle that are promising targets for gene therapy in heart failure, including the following: protein phosphatase I, adenylyl cyclase 6, G-protein-coupled receptor kinase 2, phospholamban, SUMOI, and SI00AI. These preclinical and clinical trials represent a "quiet revolution" that may end up being one of the most significant and remarkable breakthroughs in modern medical practice. Of course, a number of uncertainties remain, including the long-term utility and wisdom of improving the contractile performance of "sick" muscle cells. In this regard, gene therapy may turn out to be a way of buying additional time for actual cardiac regeneration to occur using cardiac stem cells or induced pluripotent stem cells.
\end{abstract}

\section{Introduction}

Heart failure is a leading cause of death in the United States and is mentioned in one out of nine death certificates [1]. Survival after diagnosis has improved over time; however, the death rate remains high with $\sim 50 \%$ mortality within 5 years. There is no cure for heart failure short of a heart transplant, which is an option only for a few select individuals. Thus, there is a great need for new therapies. Heart failure, and here we focus on systolic heart failure or heart failure with reduced ejection fraction, results from damage to the heart that prevents it from meeting its primary function to deliver oxygenated blood to the body. The most common causes of heart failure are coronary artery disease and hypertension, which can compromise contractility by reducing oxygen delivery to the heart muscle (or by adverse remodeling of the heart in the case of hypertension) or cause muscle damage outright through infarction. Ironically, cardiac muscle damage leading to heart failure may also result from reperfusion-injury following percutaneous coronary intervention (PCI), which is performed to increase oxygen delivery to cardiac muscle [2]. With reduced contractility, increased neurohormonal drive kicks in, causing genetic and structural changes to the heart that further reduce the ability of the heart to function as a pump [3,4]. Moreover, the increased metabolic and oxidative stress and inflammation that develop during the progression of heart failure elicit additional structural damage to the heart that also compromises pump function $[5,6]$. Thus, the trajectory of heart failure is multipronged and exponential, 
which makes therapeutic treatment difficult. At best, medicines today slow the progression of heart failure. An alternative strategy to treat heart failure is to restore the function of the heart as a pump using gene therapy. Here, we focus on successful preclinical trials that used viral gene delivery to enhance cardiac myocyte contractility by improving calcium handling, some of which have already progressed to clinical trials.

\section{Calcium handling in the failing heart}

Contraction of cardiac muscle is initiated by the influx of $\mathrm{Ca}^{2+}$ via L-type $\mathrm{Ca}^{2+}$ channels that open as a result of membrane depolarization brought about by the action potential. This $\mathrm{Ca}^{2+}$ activates the sarcoplasmic reticulum $\mathrm{Ca}^{2+}$ release channels known as ryanodine receptor 2 (RyR2), leading to a large increase in sarcoplasmic $\mathrm{Ca}^{2+}$. The rise in sarcoplasmic calcium causes contraction by $\mathrm{Ca}^{2+}$ binding to troponin $\mathrm{C}$, which relieves constraints on actin-myosin interaction and cross-bridge formation. With relaxation, $60 \%-80 \%$ of the sarcoplasmic $\mathrm{Ca}^{2+}$ is actively transported into the sarcoplasmic reticulum lumen by the sarco(endo)plasmic reticulum $\mathrm{Ca}^{2+}$-ATPase pump (SERCA2a), while the remainder exits the cardiac myocyte by way of the $\mathrm{Na}^{+}-\mathrm{Ca}^{2+}$ exchanger [7]. With heart failure, $\mathrm{Ca}^{2+}$ uptake into the sarcoplasmic reticulum is impaired due to decreased expression of SERCA2a [7]. Activity of SERCA2a is decreased as well, due to an increased association of SERCA2a with its inhibitory regulator phospholamban for two reasons: first, normally, phosphorylation of phospholamban relieves SERCA2a inhibition by causing its dissociation from SERCA2a, but, in heart failure, there is less phosphorylation of phospholamban due to increased protein phosphatase 1 (PP1) activity [8]; second, the decreased SERCA2a/phospholamban ratio means that there is more phospholamban relative to SERCA2a, thus favoring SERCA2a inhibition. In addition, the sarcoplasmic reticulum becomes leaky in heart failure due to CaMKII-dependent phosphorylation of RyR2 [9]. Thus, in the failing heart, the sarcoplasmic reticulum does not function as well in removing $\mathrm{Ca}^{2+}$ from the sarcoplasm, which has two consequences: (1) there is an increase in resting sarcoplasmic $\mathrm{Ca}^{2+}$ that contributes to reduced relaxation and diastolic dysfunction; and (2) there is less $\mathrm{Ca}^{2+}$ released from the sarcoplasmic reticulum during contraction, which means that the force of contraction is reduced [7]. Strategies to improve or restore sarcoplasmic reticulum function would be predicted to reverse heart failure.

\section{Viral gene therapy for heart failure AAV delivery}

Recombinant AAVs (adeno-associated viruses - serotypes $1,6,8$, and 9 in particular) are currently the most widely used vectors for gene delivery to the heart, mainly due to their relative selectivity for cardiac myocytes, efficient long-term transgene expression, and low immunogenicity and rates of insertional mutagenesis [10-14]. However, restricted packaging capacity and inability to evade neutralizing antibodies limit their potential therapeutic effect and usage. Strategies are currently underway to overcome these issues. Cell-specific promoters can be used to further enhance expression of the transgene in cardiac myocytes [15]. While numerous vector delivery techniques have been developed, intravascular is the least invasive but effective approach for AAV delivery to the heart, largely due to the ability of the virus to cross the capillary endothelium. To avoid post-intravenous (IV) systemic neutralization and non-cardiac tissue transduction and subsequent toxicity and titer dilution, direct and indirect intracoronary injections are preferred and proven to be more efficient [16], and these are the current mode of administrating AAV in heart failure clinical trials. Finally, although $\mathrm{AAV}$-mediated gene expression is relatively long lived, the recombinant vectors used do not integrate into the genome, making it likely that follow-up injections will be needed [17]. For more information about the different gene delivery technologies the reader is referred to an excellent recent review by MG Katz et al. [18].

SERCA2 $a$ on trial: a new era for heart failure management Impaired SERCA2a activity is associated with high diastolic but low systolic $\mathrm{Ca}^{2+}$ levels, which correlate with poor disease prognosis [19]. Overwhelming preclinical evidence from animal models has shown the importance of SERCA2a in heart failure and the power of treating heart failure by increasing SERCA2a expression by means of viral transduction of a SERCA2a transgene [20-23]. In 2007, Celladon Corporation sponsored the first Phase I/II human clinical trial ([24] CUPID; NCT00454818) in which a SERCA2a transgene was transferred, via an AAV1 Vector (MYDICAR), by percutaneous intra-coronary infusion. No safety concerns were revealed by the Phase I open label and sequential dose escalating part of the trial involving nine heart failure patients. A small Phase II, 3-doses, randomized, doubleblind, placebo-controlled trial enrolling 39 heart failure patients followed. In addition to supporting the earlier safety findings, this trial reported significant clinical improvement of cardiac remodeling and heart failure symptoms. These results were accompanied by a marked reduction in cardiovascular hospitalization and clinical events that persisted for 6 to 12 months post high-dose treatment [25]. A larger Phase II, randomized, doubleblind, placebo-controlled, multinational and multicenter clinical trial A Study of Genetically Targeted Enzyme Replacement Therapy for Advanced Heart Failure (CUPID-2b) is currently underway (NCT01643330). This trial will hopefully overcome the limitations of the small studies and 
confirm the efficacy of gene therapy in the management of heart failure. Details on the clinical trials involving AAV-mediated SERCA2a gene therapy are summarized in Table 1.

\section{Other potential targets}

In addition to SERCA2a, many calcium cycling proteins are potential therapeutic targets in heart failure (Figure 1) [17]. Preclinical gene therapy studies targeting these molecules, directly or indirectly, support their safety and efficacy in improving cardiac function (Table 2). Their assessment as targets for heart failure management in clinical trials is likely.

\section{Protein phosphatase I}

Protein phosphatase (PP1) $\beta$ is the catalytic subunit isoform of PP1 that primarily suppresses sarcoplasmic reticulum $\mathrm{Ca}^{2+}$ uptake by dephosphorylating phospholamban. Knockdown of the PP1 $\beta$ using short-hairpin (sh)RNA improved cardiac function and reduced cardiac remodeling and interstitial fibrosis in the muscle LIM protein-deficient mouse model of heart failure $[26,27]$. shRNA was delivered with an AAVy vector under the control of a B-type natriuretic protein (BNP) promoter to achieve heart failure-inducible gene expression.

\section{Adenylyl cyclase 6}

$\beta$-Adrenergic enhancement of contraction of the heart is mediated in part through adenylyl cyclase 6 (AC6), which converts ATP to cAMP and, thus, activates protein kinase A (PKA). PKA phosphorylates phospholamban to enhance SERCA2a activity and cardiac troponin I to enhance the force of contraction and relaxation [28-30]. In AC6 knockout hearts, phospholamban phosphorylation and SERCA2a activity are reduced [28]. Viral delivery of an AC6 transgene has been shown effective in alleviating heart failure symptoms in both small and large animal models of heart failure, due to improved sarcoplasmic reticulum $\mathrm{Ca}^{2+}$ function and storage resulting from increased phospholamban phosphorylation and decreased PP1 expression [31-34]. AC6 may also decrease phospholamban expression independently of cAMP formation [28].

\section{GRK2}

The serine/threonine kinase GRK2 (G-protein-coupled receptor kinase) attenuates $\beta$-adrenergic signaling in the heart due to receptor desensitization and downregulation [35]. Levels and activity of GRK2 are increased in heart failure due to over-activation of the compensatory sympathetic drive. Viral-mediated knockdown of GRK2 in cardiac muscle is, thus, a viable strategy for enhancing cardiac contractility, while its knockdown in the adrenal gland helps reduce the increased circulating levels of catecholamines observed in heart failure [35].

\section{Phospholamban}

Phospholamban is a small, 52 amino acid protein that binds SERCA2a as a monomer and inhibits its activity [36]. Phosphorylation of phospholamban causes dissociation from SERCA2a and favors the formation of pentamers that are functionally inactive towards SERCA2a. Several strategies have been used to target phospholamban in models of heart failure using viral delivery, including expression of a chicken antibody-derived protein targeting phospholamban, an inhibitory phospholamban peptide, antisense, a zinc-finger transcriptional repressor, and a pseudophosphorylated mutant of phospholamban. Improvements in contractility and $\mathrm{Ca}^{2+}$ handling of cardiac myocytes have been reported.

Table I. Clinical trials on SERCA2a for heart failure

\begin{tabular}{|c|c|c|c|c|}
\hline & \multicolumn{4}{|c|}{ Clinical Trial } \\
\hline & NCT004548I8 & NCT00534703 & NCT004548I8 & NCT0I 643330 \\
\hline Acronym & CUPID & NA & CUPID & CUPID-2b \\
\hline Sponsor & Celladon Corporation & Imperial College London & Celladon Corporation & Celladon Corporation \\
\hline Study design & OL/SDE & $\mathrm{R} / \mathrm{DB} / \mathrm{PC}$ & $\mathrm{R} / \mathrm{DB} / \mathrm{PC}$ & $\mathrm{R} / \mathrm{DB} / \mathrm{PC}$ \\
\hline \multirow[t]{2}{*}{ Outcome measures } & Safety & Safety & Safety & Efficacy \\
\hline & Efficacy & Efficacy & Efficacy & \\
\hline Drug/Vector & $\begin{array}{l}\text { MYDICAR (AAVI- } \\
\text { CMV-SERCA2a) }\end{array}$ & AAV6.-CMV-SERCA2a & $\begin{array}{c}\text { MYDICAR (AÁVI-CMV- } \\
\text { SERCA2a) }\end{array}$ & $\begin{array}{c}\text { MYDICAR (AAVI-CMV- } \\
\text { SERCA2a) }\end{array}$ \\
\hline \multirow{3}{*}{ Doses (DRP) } & $1.4 \times 10^{11}$ & $5 \times 10^{12}$ & $6 \times 10^{11}$ & $1 \times 10^{13}$ \\
\hline & $6 \times 10^{11}$ & & $3 \times 10^{12}$ & \\
\hline & $3 \times 10^{12}$ & & $1 \times 10^{13}$ & \\
\hline Delivery & AECAI & AECAI & AECAI & AECAI \\
\hline Phase & $\mathrm{PI}$ & $\mathrm{Pl} / \mathrm{PII}$ & PII & PII \\
\hline N-Status & 9 patients-completed & 16 patients-unknown & 39 patients-completed & 200-recruiting \\
\hline Results & Positive & NA & Positive & NA \\
\hline PMID & 19327618 & NA & 21709064 & NA \\
\hline
\end{tabular}

$\mathrm{AECl}$, antegrade epicardial coronary artery infusion; DB, double-blinded; DRP, DNase resistant particles; NA, not applicable; OL, open label; PI, Phase I; PII, Phase II; PC, placebo-controlled; R, randomized; SDE, sequential dose escalation. 
Figure I. Targeting calcium handling proteins in heart failure

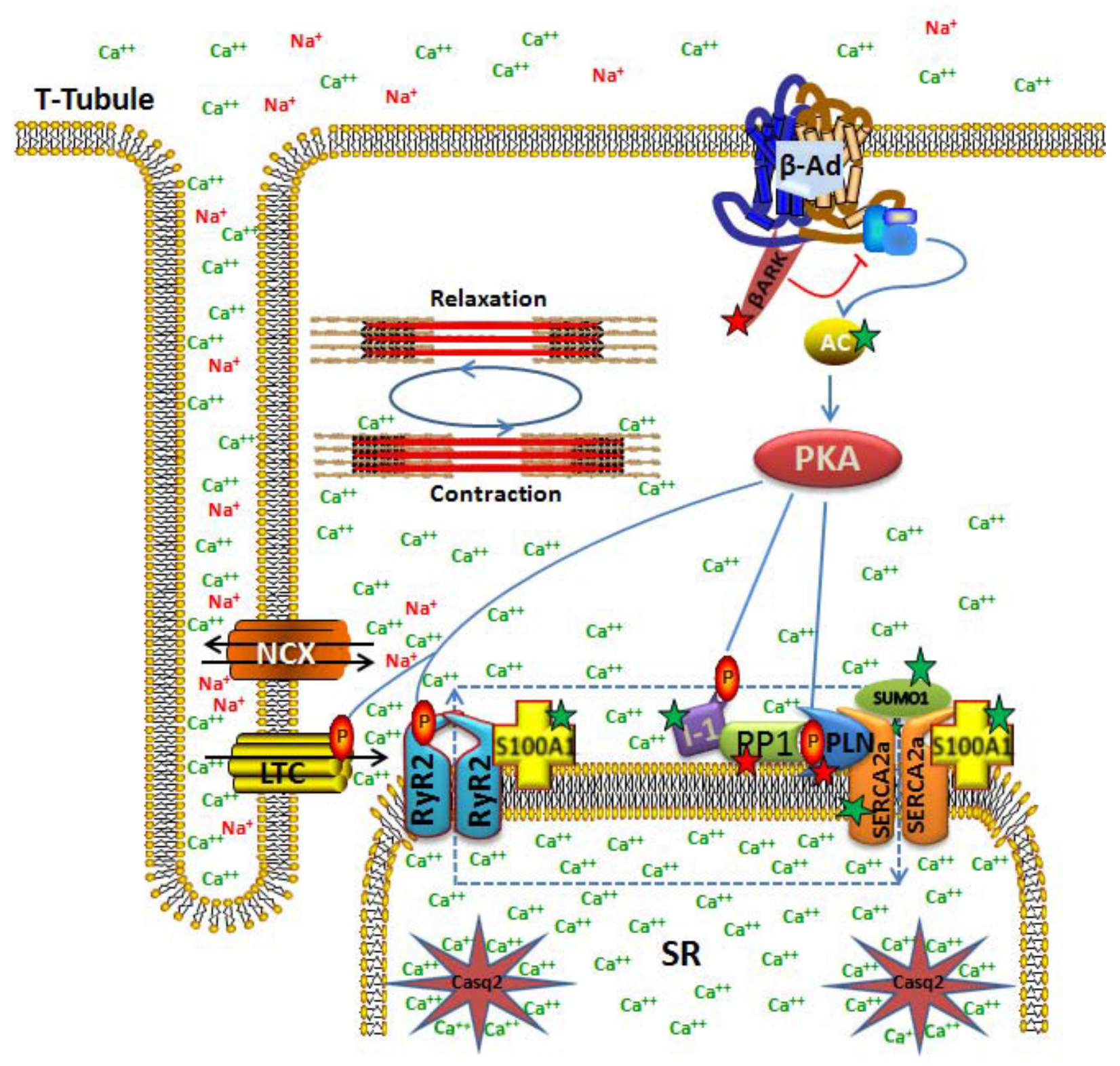

Influx of $\mathrm{Ca}^{2+}$ via L-type $\mathrm{Ca}^{2+}$ channels (LTC) that open with membrane depolarization activates the sarcoplasmic reticulum (SR) $\mathrm{Ca}^{2+}$ release channels known as ryanodine receptor 2 (RyR2), leading to a large increase in sarcoplasmic $\mathrm{Ca}^{2+}$ and muscle contraction. With relaxation, most of the sarcoplasmic $\mathrm{Ca}^{2+}$ is actively transported into the SR lumen by the sarco(endo)plasmic reticulum $\mathrm{Ca}^{2+}$-ATPase pump (SERCA2a) and bound to calsequestrin 2 (Casq2), while the remainder exits the cardiac myocyte by way of the $\mathrm{Na}^{+}-\mathrm{Ca}^{2+}$ exchanger (NCX). Sumoylation by SUMOI increases SERCA2a activity and protein levels. Phospholamban (PLN) inhibits SERCA2a and this inhibition is relieved by phosphorylation (P) of PLN by protein kinase $\mathrm{A}(\mathrm{PKA})$ and Ca ${ }^{2+}$-calmodulin-dependent protein kinase (CaMKIl; not shown). Dephosphorylation of PLN by protein phosphatase I (PPI) restores inhibition. PPI inhibitor-I (I-I) opposes the actions of PPI, thus favoring increased SERC2a activity. Activation of $\beta$-adrenergic ( $\beta$-Ad) receptors leads to an increased activity of adenylyl cyclase (AC), e.g. AC6, and cAMP formation, which in turn activates PKA. $\beta$-Ad receptors are desensitized by the serine/threonine kinase $\beta$ adrenergic receptor kinase, also referred to as BARK or G-protein-coupled receptor kinase 2 (GRK2). Besides PLN phosphorylation, PKA enhances contraction by phosphorylating and activating LTC, RyR2 and $\mathrm{I}-\mathrm{I}$. The $\mathrm{Ca}^{2+}$ binding chaperone protein SIO0AI enhances RyR2 and SERCA2a activity, favoring enhanced calcium turnover during the contractile cycle. Heart failure is associated with reduced expression of SERCA2a and SUMOI, and increased levels of PPI and GRK2, thereby reducing heart contraction by depleting SR Ca ${ }^{2+}$ stores and adrenergic stimulation. AAV-mediated gene delivery strategies to increase SERCA2a activity or expression, directly or indirectly by increasing (green star) SUMOI, SIOOAI, AC6, and I-I activity/expression, or by decreasing (red star) PPI, PLN, or GRK2 activity/expression have proven beneficial in preclinical models of heart failure. The approach of directly increasing SERCA2a has proven beneficial in early clinical trials. See text for additional details. 
Table 2. Summary of preclinical trials targeting calcium handling protein by viral gene therapy that showed benefit for treating heart failure

\begin{tabular}{|c|c|c|c|c|}
\hline Targets & Role & Vector/Animals & Objective & Status/Comments \\
\hline Adenylyl cyclase 6 AC6 & $\begin{array}{l}\text { Indirect increase in } \\
\text { SERCA2a activity }\end{array}$ & $\begin{array}{c}\text { Ad-mouse [31,32]/pig } \\
{[33,34]}\end{array}$ & Upregulation & Ad5.h-AC6 PI/Il clinical trial \\
\hline $\begin{array}{l}\text { G protein-coupled receptor } \\
\text { kinase (GRK2) }\end{array}$ & $\begin{array}{c}\text { Desensitize } \\
\beta \text {-adrenergic receptor }\end{array}$ & $\begin{array}{c}\text { Ad-rabbit }[47,48] \\
\text { AAV6-sheep }[49,50] / \text { rat }[5 \mathrm{I}]\end{array}$ & Inhibition & Very promising \\
\hline Phospholamban (PLN) & Inhibits SERCA2a activity & $\begin{array}{c}\text { Ad-Hamster [52]/sheep [53] } \\
\text { AAV-mouse [54]/hamster } \\
{[55] / \text { rat }[56,57]}\end{array}$ & $\begin{array}{l}\text { Downregulation and/or } \\
\text { limiting activity }\end{array}$ & $\begin{array}{l}\text { Promising (Optimization } \\
\text { required) }\end{array}$ \\
\hline Protein phosphatase I (PPI) & $\begin{array}{l}\text { Indirect inhibition of } \\
\text { SERCA2a activity via PLB } \\
\text { dephosphorylation }\end{array}$ & $\begin{array}{l}\text { Ad-hamster [58] } \\
\text { AAV9-mouse [26] }\end{array}$ & Downregulation/Inhibition & $\begin{array}{l}\text { Promising (more studies } \\
\text { required) }\end{array}$ \\
\hline $\begin{array}{l}\text { SI } 00 \text { calcium-binding protein } \\
\text { AI (SIOOAI) }\end{array}$ & $\begin{array}{c}\text { Enhances SERCA2a/RyR2 } \\
\text { and SR Ca }{ }^{2+} \text { cycling } \\
\text { proteins activity }\end{array}$ & $\begin{array}{l}\text { Ad-rat [39] } \\
\text { AAV6-rats [40] } \\
\text { AAV9-pigs [41] }\end{array}$ & Upregulation & Very promising \\
\hline $\begin{array}{l}\text { Small ubiquitin-related } \\
\text { modifier I (SUMOI) }\end{array}$ & $\begin{array}{l}\text { Promotes SERCA2a protein } \\
\text { stability and activity }\end{array}$ & AAV9-mouse [37] & Upregulation & $\begin{array}{l}\text { Promising (more studies } \\
\text { required) }\end{array}$ \\
\hline SR Ca ${ }^{2+}$-ATPase (SERCA2a) & $\mathrm{Ca}^{2+}$ storage during diastole & $\begin{array}{l}\text { AAVI-rat }[20] / \text { pig }[21] \\
\text { AAV2-sheep }[22,59] \\
\text { AAV6-sheep }[60]\end{array}$ & Upregulation & $\begin{array}{l}\text { AAVI- SERCA2a PII } \\
\text { clinical trial }\end{array}$ \\
\hline
\end{tabular}

Ad, adenovirus; AAV, adeno-associated virus; PI, Phase I; PII, Phase II.

\section{SUMOI}

Sumoylation is posttranslational modification of SERCA2a that was recently identified as highly relevant to development and potential treatment of heart failure [37]. SERCA2a is sumoylated by SUMO1 on two specific lysine residues in the heart and levels of SERCA2a sumoylation are reduced in the failing human heart and animal models of the failing heart, as are levels of SUMO1 and SERCA2a. Restoration of SUMO1 during transverse aortic constriction-induced heart failure in the mouse by recombinant AAV9 improved cardiac function. Evidence was provided that sumoylation increases both SERCA2a ATPase activity and protein stability. Although SUMO1 seems like a promising target for treating heart failure, its broad-based action in cardiac myocytes may prove an insurmountable limitation [38].

SIOOAI

This is a $\mathrm{Ca}^{2+}$ binding protein that is highly expressed in cardiac myocytes, where it localizes at the sarcoplasmic reticulum, mitochondria, and myofilaments [36]. S100A1 interacts with SERCA2a, phospholamban, and RyR2. Exact details are not defined, but S100A1 seems to function as a $\mathrm{Ca}^{2+}$-sensitive chaperone that enhances the activity of other proteins. End-stage failing human hearts have reduced levels of S100A1 protein, and a number of gene therapy studies have shown the utility of increasing expression of S100A1 to improve cardiac function in heart failure [39-41].

\section{A cautionary note}

Results of clinical trials are needed before the utility of gene therapy to treat heart failure can be adequately assessed. A negative outcome in the absence of any serious adverse events may slow, but not deter, further research into this approach. For one thing, there is a certain attractiveness to the simplicity of the idea of treating heart failure by restoring cardiac muscle performance. Of course that begs the question of whether it makes sense to "flog" an already "sick" cardiac muscle cell to make it work harder. Gene therapy to do so may turn out simply to be a way of buying additional time for true myocardial regeneration to take place using cardiac or induced-pluripotent stem cells. The reader is referred to several recent review articles dealing with stem cell therapy in heart failure [42-45].

\section{Summary and future perspectives}

Heart failure is a major health issue with a high rate of crippling morbidity and mortality. In the USA, the total annual cost of heart failure is estimated to be greater than 30 billion dollars and is expected to more than double over the next decade, due to an aging population [46]. Thus, there is a substantial need for new strategies to prevent the progression of heart failure. Until now, heart failure was seen as an incurable disease. For the first time, results of recent clinical trials using a viral-delivery gene therapy approach have offered the promise of an effective therapy for reversing systolic heart failure. These trials are the outgrowth of the methodical approach of basic research in identifying viable targets to enhance cardiac contractility. Time will tell whether a single target approach is sufficient to restore heart function and prevent deterioration or whether multiple gene targets are needed along with stem cell therapy to eventually replace the injured myocardium. Using a viral-delivery gene therapy approach to treat heart failure by enhancing contractility is not yet a reality, but substantial progress in that direction has been made in the last few years. 


\section{Abbreviations}

AAV, adeno-associated virus; AC, adenylyl cyclase; GRK2, G-protein-coupled receptor kinase 2; IV, intravenous; PKA, protein kinase A; PP1, protein phosphatase 1; RyR2, ryanodine receptor 2; SERCA2a, sarco(endo)plasmic reticulum $\mathrm{Ca}^{2+}$-ATPase pump.

\section{Disclosures}

The authors declare that they have no disclosures.

\section{Acknowledgments}

This work was supported by grant R01 HL088101 from The National Heart, Lung, and Blood Institute (NHLBI) to George W. Booz.

\section{References}

I. Writing Group Members, Roger VL, Go AS, Lloyd-Jones DM, Benjamin EJ, Berry JD, Borden WB, Bravata DM, Dai S, Ford ES, Fox CS, Fullerton HJ, Gillespie C, Hailpern SM, Heit JA, Howard VJ, Kissela BM, Kittner SJ, Lackland DT, Lichtman JH, Lisabeth LD, Makuc DM, Marcus GM, Marelli A, Matchar DB, Moy CS, Mozaffarian D, Mussolino ME, Nichol G, Paynter NP, Soliman EZ, Sorlie PD, Sotoodehnia N, Turan TN, Virani SS, Wong ND, Woo D, Turner MB; on behalf of the American Heart Association Statistics Committee and Stroke Statistics Subcommittee; On behalf of the American Heart Association Statistics Committee and Stroke Statistics Subcommittee: Heart Disease and Stroke Statistics2012 Update: A Report From the American Heart Association. Circulation 2012, I25:e2-e220.

2. Fröhlich GM, Meier P, White SK, Yellon DM, Hausenloy DJ: Myocardial reperfusion injury: looking beyond primary $\mathrm{PCl}$. Eur Heart J 20I3, Apr 8. [Epub ahead of print].

\section{FIOOOPrime}

3. van Berlo JH, Maillet M, Molkentin JD: Signaling effectors underlying pathologic growth and remodeling of the heart. J Clin Invest 2013, 123:37-45.

\section{FlOOOPrime}

4. Distefano G, Sciacca P: Molecular pathogenesis of myocardial remodeling and new potential therapeutic targets in chronic heart failure. Ital J Pediatr 20I2 Sep 12, 38:4I.

5. Ahn J, Kim J: Mechanisms and consequences of inflammatory signaling in the myocardium. Curr Hypertens Rep 2012, 14:5 I0-516.

6. Sawyer DB: Oxidative stress in heart failure: what are we missing? Am J Med Sci 20I I, 342: I20-I 24.

\section{FlOOOPrime
RECOMMENDED}

7. Zarain-Herzberg A, Estrada-Avilés R, Fragoso-Medina J: Regulation of sarco(endo)plasmic reticulum $\mathrm{Ca}^{2+}$-ATPase and calsequestrin gene expression in the heart. Can J Physiol Pharmacol 2012, 90:1017-1028.

\section{FIOOOPrime}

\section{RECOMMENDED}

8. Gupta RC, Mishra S, Rastogi S, Imai M, Habib O, Sabbah HN: Cardiac SR-coupled PPI activity and expression are increased and inhibitor I protein expression is decreased in failing hearts. Am J Physiol Heart Circ Physiol 2003, 285:H2373-H238I.

\section{FlOOOPrime \\ RECOMMENDED}

9. Ai X, Curran JW, Shannon TR, Bers DM, Pogwizd SM: $\mathrm{Ca}^{2+}$ I calmodulin-dependent protein kinase modulates cardiac ryanodine receptor phosphorylation and sarcoplasmic reticulum $\mathrm{Ca}^{2+}$ leak in heart failure. Circ Res 2005, 97:| 3| |4- I322.

\section{FIOOOPrime}

10. Rivera VM, Gao GP, Grant RL, Schnell MA, Zoltick PW, Rozamus LW, Clackson T, Wilson JM: Long-term pharmacologically regulated expression of erythropoietin in primates following AAVmediated gene transfer. Blood 2005, 105:1424-1430.

II. Hildinger M, Auricchio A, Gao G, Wang L, Chirmule N, Wilson JM: Hybrid vectors based on adeno-associated virus serotypes 2 and 5 for muscle-directed gene transfer. J Virol 200I, 75:6I99-6203.

12. Wang Z, Ma HI, Li J, Sun L, Zhang J, Xiao X: Rapid and highly efficient transduction by double-stranded adeno-associated virus vectors in vitro and in vivo. Gene Ther 2003, 10:2105-2111.

13. Qi Y, Liu X, Li H, Shenoy V, Li Q, Hauswirth WW, Sumners C, Katovich MJ: Selective tropism of the recombinant adenoassociated virus 9 serotype for rat cardiac tissue. J Gene Med 2010, I2:22-34.

14. Palomeque J, Chemaly ER, Colosi P, Wellman JA, Zhou S, Del Monte F, Hajjar RJ: Efficiency of eight different AAV serotypes in transducing rat myocardium in vivo. Gene Ther 2007, 14:989-997.

15. Pacak CA, Sakai Y, Thattaliyath BD, Mah CS, Byrne BJ: Tissue specific promoters improve specificity of AAV9 mediated transgene expression following intra-vascular gene delivery in neonatal mice. Genet Vaccines Ther 2008, 6:13.

16. Fang $\mathrm{H}$, Lai NC, Gao MH, Miyanohara A, Roth DM, Tang T, Hammond HK: Comparison of Adeno-Associated Virus Serotypes and Delivery Methods for Cardiac Gene Transfer. Hum Gene Ther Methods 2012, 23:234-24I.

17. Kairouz V, Lipskaia L, Hajjar RJ, Chemaly ER: Molecular targets in heart failure gene therapy: current controversies and translational perspectives. Ann N Y Acad Sci 20I2, I 254:42-50.

18. Katz MG, Fargnoli AS, Pritchette LA, Bridges CR: Gene delivery technologies for cardiac applications. Gene Ther 2012, 19:659-669.

\section{FIOOOPrime}

19. Gianni D, Chan J, Gwathmey JK, del Monte F, Hajjar RJ: SERCA2a in heart failure: role and therapeutic prospects. J Bioenerg Biomembr 2005, 37:375-380.

20. Sakata S, Lebeche D, Sakata N, Sakata Y, Chemaly E, Liang L, Tsuji T, Takewa Y, del Monte F, Peluso R, Zsebo K, Jeong D, Park WJ, Kawase Y, Hajjar RJ: Restoration of mechanical and energetic function in failing aortic-banded rat hearts by gene transfer of calcium cycling proteins. J Mol Cell Cardiol 2007, 42:852-86I.

\section{FlOOOPrime} RECOMMENDED

21. Kawase Y, Ly HQ, Prunier F, Lebeche D, Shi Y, Jin H, Hadri L, Yoneyama R, Hoshino K, Takewa Y, Sakata S, Peluso R, Zsebo K, Gwathmey JK, Tardif JC, Tanguay JF, Hajjar RJ: Reversal of cardiac dysfunction after long-term expression of SERCA2a by gene transfer in a pre-clinical model of heart failure. J Am Coll Cardiol 2008, 5 I: IIII2-III9.

\section{FlOOOPrime}

\section{RECOMMENDED}

22. Byrne M, Power J, Preovolos A, Mariani J, Hajjar R, Kaye D: Recirculating cardiac delivery of AAV2/ISERCA2a improves myocardial function in an experimental model of heart failure in large animals. Gene Ther 2008, 15:1550-1557.

\section{FlOOOPrime}

23. Mariani JA, Smolic A, Preovolos A, Byrne MJ, Power JM, Kaye DM: Augmentation of left ventricular mechanics by recirculationmediated AAV2/I-SERCA2a gene delivery in experimental heart failure. Eur J Heart Fail 20 I I, 13:247-253. 
24. Jaski BE, Jessup ML, Mancini DM, Cappola TP, Pauly DF, Greenberg B, Borow K, Dittrich H, Zsebo KM, Hajjar RJ: Calcium Up-Regulation by Percutaneous Administration of Gene Therapy In Cardiac Disease (CUPID) Trial Investigators. Calcium upregulation by percutaneous administration of gene therapy in cardiac disease (CUPID Trial), a first-in-human phase $1 / 2$ clinical trial. J Card Fail 2009, I5:17|-|8|.

\section{FlOOOPRime
RECOMMENDED}

25. Jessup M, Greenberg B, Mancini D, Cappola T, Pauly DF, Jaski B, Yaroshinsky A, Zsebo KM, Dittrich H, Hajjar RJ: Calcium Upregulation by Percutaneous Administration of Gene Therapy in Cardiac Disease (CUPID) Investigators. Calcium Upregulation by Percutaneous Administration of Gene Therapy in Cardiac Disease (CUPID): a phase 2 trial of intracoronary gene therapy of sarcoplasmic reticulum $\mathrm{Ca}^{2+}$-ATPase in patients with advanced heart failure. Circulation 20 I , I 24:304-313.

\section{FlOOOPRime
RECOMMENDED}

26. Miyazaki $Y$, Ikeda $Y$, Shiraishi K, Fujimoto SN, Aoyama H, Yoshimura K, Inui M, Hoshijima M, Kasahara H, Aoki H, Matsuzaki M: Heart failureinducible gene therapy targeting protein phosphatase I prevents progressive left ventricular remodeling. PLOS One 2012, 7:e35875

27. Aoyama H, lkeda $\mathrm{Y}$, Miyazaki $\mathrm{Y}$, Yoshimura K, Nishino S, Yamamoto T, Yano M, Inui M, Aoki H, Matsuzaki M: Isoformspecific roles of protein phosphatase I catalytic subunits in sarcoplasmic reticulum-mediated $\mathrm{Ca}^{2+}$ cycling. Cardiovasc Res 201I, 89:79-88.

\section{FlOOOPrime} RECOMMENDED

28. Tang T, Gao MH, Hammond HK: Prospects for gene transfer for clinical heart failure. Gene Ther 2012, 19:606-612.

\section{FlOOOPrime}

29. Wijnker PJ, Foster DB, Tsao AL, Frazier AH, dos Remedios CG, Murphy AM, Stienen GJ, van der Velden J: Impact of site-specific phosphorylation of protein kinase A sites Ser23 and Ser24 of cardiac troponin I in human cardiomyocytes. Am J Physiol Heart Circ Physiol 2013, 304:H260-H268.

30. Tang T, Hammond HK, Firth A, Yang Y, Gao MH, Yuan JX, Lai NC: Adenylyl cyclase 6 improves calcium uptake and left ventricular function in aged hearts. J Am Coll Cardiol 201I, 57:1846-1855.

31. Roth DM, Lai NC, Gao MH, Drumm JD, Jimenez J, Feramisco JR, Hammond HK: Indirect intracoronary delivery of adenovirus encoding adenylyl cyclase increases left ventricular contractile function in mice. Am J Physiol Heart Circ Physiol 2004, 287: $\mathrm{HI} 72-\mathrm{HI} 77$.

\section{FlOOOPrime}

32. Rebolledo B, Lai NC, Gao MH, Takahashi T, Roth DM, Baird SM, Hammond HK: Adenylyl cyclase gene transfer increases function of the failing heart. Hum Gene Ther 2006, 17:1043-1048.

\section{FlOOOPrime}

\section{RECOMMENDED}

33. Lai NC, Roth DM, Gao MH, Tang T, Dalton N, Lai YY, Spellman M, Clopton P, Hammond HK: Intracoronary adenovirus encoding adenylyl cyclase $\mathrm{VI}$ increases left ventricular function in heart failure. Circulation 2004, I 1 0:330-336.

\section{FlOOOPrime}

34. Lai NC, Roth DM, Gao MH, Fine S, Head BP, Zhu J, McKirnan MD, Kwong C, Dalton N, Urasawa K, Roth DA, Hammond HK: Intracoronary delivery of adenovirus encoding adenylyl cyclase $\mathrm{VI}$ increases left ventricular function and cAMP-generating capacity. Circulation 2000, 102:2396-240 I.

\section{FlOOOPrime}

35. Reinkober J, Tscheschner H, Pleger ST, Most P, Katus HA, Koch WJ, Raake PW: Targeting GRK2 by gene therapy for heart failure: benefits above $\beta$-blockade. Gene Ther 2012, 19:686-693.

\section{FIOOOPrime}

RECOMMENDED

36. Kranias EG, Hajjar RJ: Modulation of cardiac contractility by the phospholamban/SERCA2a regulatome. Circ Res 2012, I I0: 1646-1660.

\section{FlOOOPrime}

RECOMMENDED

37. Kho C, Lee A, Jeong D, Oh JG, Chaanine AH, Kizana E, Park WJ, Hajjar RJ: SUMOI-dependent modulation of SERCA2a in heart failure. Nature 20II, 477:60I-605.

\section{FlOOOPrime}

RECOMMENDED

38. Shenoy SK, Rockman HA: Cardiovascular biology: heart fails without pump partner. Nature 20II, 477:546-547.

\section{FlOOOPrime
RECOMMENDED}

39. Most P, Pleger ST, Volkers M, Heidt B, Boerries M, Weichenhan D, Löffler E, Janssen PM, Eckhart AD, Martini J, Williams ML, Katus HA, Remppis A, Koch W]: Cardiac adenoviral SI 00AI gene delivery rescues failing myocardium. J Clin Invest 2004, I I4: I550-I563.

\section{FlOOOPrime}

\section{RECOMMENDED}

40. Pleger ST, Most P, Boucher M, Soltys S, Chuprun JK, Pleger W, Gao E, Dasgupta A, Rengo $G$, Remppis A, Katus HA, Eckhart AD, Rabinowitz JE, Koch W]: Stable myocardial-specific AAV6SIO0AI gene therapy results in chronic functional heart failure rescue. Circulation 2007, II 5:2506-25I5.

\section{FIOOOPrime}

RECOMMENDED

4I. Pleger ST, Shan C, Ksienzyk J, Bekeredjian R, Boekstegers P, Hinkel R, Schinkel S, Leuchs B, Ludwig J, Qiu G, Weber C, Raake P, Koch WJ, Katus HA, Müller OJ, Most P: Cardiac AAV9-SI00AI gene therapy rescues post-ischemic heart failure in a preclinical large animal model. Sci Transl Med 20I I, 3:92ra64.

\section{FlOOOPrime}

42. Anversa $P$, Kajstura J, Rota M, Leri A: Regenerating new heart with stem cells. J Clin Invest 2013, 1 23:62-70.

43. Pal SN, Kofidis T: New cell therapies in cardiology. Expert Rev Cardiovasc Ther 2012, 10:1023-1037.

44. Kikuchi K, Poss KD: Cardiac regenerative capacity and mechanisms. Annu Rev Cell Dev Biol 2012, 28:719-4I.

45. Chong JJ: Cell therapy for left ventricular dysfunction: an overview for cardiac clinicians. Heart Lung Circ 2012, 21:532-542.

46. Heidenreich PA, Albert NM, Allen LA, Bluemke DA, Butler J, Fonarow GC, Ikonomidis JS, Khavjou O, Konstam MA, Maddox TM, Nichol G, Pham M, Piña IL, Trogdon JG; on behalf of the American Heart Association Advocacy Coordinating Committee, Council on Arteriosclerosis, Thrombosis and Vascular Biology, Council on Cardiovascular Radiology and Intervention, Council on Clinical Cardiology, Council on Epidemiology and Pr: Forecasting the Impact of Heart Failure in the United States: A Policy Statement From the American Heart Association. Circ Heart Fail 2013, Apr 24. [Epub ahead of print].

47. Shah AS, White DC, Emani S, Kypson AP, Lilly RE, Wilson K, Glower DD, Lefkowitz RJ, Koch WJ: In vivo ventricular gene delivery of a $\beta$-adrenergic receptor kinase inhibitor to the failing heart reverses cardiac dysfunction. Circulation 200I, I03: $13 \mid 1-1316$ 
48. Tevaearai HT, Walton GB, Keys JR, Koch WJ, Eckhart AD: Acute ischemic cardiac dysfunction is attenuated via gene transfer of a peptide inhibitor of the $\beta$-adrenergic receptor kinase (3ARKI). J Gene Med 2005, 7: I I72-II77.

49. Katz MG, Fargnoli AS, Swain JD, Tomasulo CE, Ciccarelli M, Huang ZM, Rabinowitz JE, Bridges CR: AAV6-3ARKct gene delivery mediated by molecular cardiac surgery with recirculating delivery (MCARD) in sheep results in robust gene expression and increased adrenergic reserve. J Thorac Cardiovasc Surg 2012, 143:720-726.

50. Swain JD, Fargnoli AS, Katz MG, Tomasulo CE, Sumaroka M, Richardville KC, Koch W], Rabinowitz JE, Bridges CR: MCARDmediated gene transfer of GRK2 inhibitor in bovine model of acute myocardial infarction. J Cardiovasc Transl Res 2013, 6:253-262.

5I. Rengo G, Lymperopoulos A, Zincarelli C, Donniacuo M, Soltys S, Rabinowitz JE, Koch WJ: Myocardial adeno-associated virus serotype 6-3ARKct gene therapy improves cardiac function and normalizes the neurohormonal axis in chronic heart failure. Circulation 2009, I I 9:89-98.

52. Dieterle T, Meyer M, Gu Y, Belke DD, Swanson E, Iwatate M, Hollander J, Peterson KL, Ross J Jr, Dillmann WH: Gene transfer of a phospholamban-targeted antibody improves calcium handling and cardiac function in heart failure. Cardiovasc Res 2005, 67:678-688

53. Kaye DM, Preovolos A, Marshall T, Byrne M, Hoshijima M, Hajjar R, Mariani JA, Pepe S, Chien KR, Power JM: Percutaneous cardiac recirculation-mediated gene transfer of an inhibitory phospholamban peptide reverses advanced heart failure in large animals. J Am Coll Cardiol 2007, 50:253-260.

54. Andino LM, Takeda M, Kasahara H, Jakymiw A, Byrne BJ, Lewin AS: AAV-mediated knockdown of phospholamban leads to improved contractility and calcium handling in cardiomyocytes. J Gene Med 2008, 10:132-42.

55. Hoshijima M, Ikeda $Y$, Iwanaga $Y$, Minamisawa $S$, Date MO, Gu $Y$, Iwatate M, Li M, Wang L, Wilson JM, Wang Y, Ross J Jr, Chien KR: Chronic suppression of heart-failure progression by a pseudophosphorylated mutant of phospholamban via in vivo cardiac rAAV gene delivery. Nat Med 2002, 8:864-87।.

56. Zhao XY, Hu SJ, Li J, Mou Y, Bian K, Sun J, Zhu ZH: rAAV-asPLB transfer attenuates abnormal sarcoplasmic reticulum $\mathrm{Ca}^{2+}$. ATPase activity and cardiac dysfunction in rats with myocardial infarction. Eur J Heart Fail 2008, 10:47-54.

57. Zhang HS, Liu D, Huang $Y$, Schmidt S, Hickey R, Guschin D, Su H, Jovin IS, Kunis M, Hinkley S, Liang Y, Hinh L, Spratt SK, Case CC, Rebar E], Ehrlich BE, Gregory PD, Giordano F): A designed zincfinger transcriptional repressor of phospholamban improves function of the failing heart. Mol Ther 2012, 20:1508-1515.

58. Yamada M, Ikeda Y, Yano M, Yoshimura K, Nishino S, Aoyama H, Wang L, Aoki H, Matsuzaki M: Inhibition of protein phosphatase I by inhibitor-2 gene delivery ameliorates heart failure progression in genetic cardiomyopathy. FASEB J 2006, 20:1197-1199.

59. Mariani JA, Smolic A, Preovolos A, Byrne MJ, Power JM, Kaye DM: Augmentation of left ventricular mechanics by recirculationmediated AAV2/I-SERCA2a gene delivery in experimental heart failure. Eur J Heart Fail 20II, 13:247-53.

60. Beeri R, Chaput M, Guerrero JL, Kawase Y, Yosefy C, Abedat S, Karakikes I, Morel C, Tisosky A, Sullivan S, Handschumacher MD, Gilon D, Vlahakes G], Hajiar RJ, Levine RA: Gene delivery of sarcoplasmic reticulum calcium ATPase inhibits ventricular remodeling in ischemic mitral regurgitation. Circ Heart Fail 2010, 3:627-634. 